Беляченко В. В.

(0000-0003-3938-5158)

Бобров С. В., канд. техн. наук, доцент

(0000-0002-9647-9700)

Утюшев М. К.

(0000-0002-7386-7831)

Центр воєнно-стратегічних досліджень Національного університету оборони України імені Івана Черняховського, Київ

\title{
Управління ризиками створення елементів автоматизованих систем управління
}

Резюме. У статті наведено дослідницькі дані щодо ризиків IT-проєктів, продемонстровано метод оцінювання впливу, ймовірності та значущості за допомогою вербально-числової шкали Харрингтона на прикладі створення елементів автоматизованої системи управління. Результати оцінювання ризиків запропонованим методом можуть бути використані для наукового обгрунтування заходів 3 обробляння ризиків, характерних для проєктів створення автоматизованих систем.

Ключові слова: ризики IT-проєктів; метод оцінювання ризиків, шкала Харрингтона.

Постановка проблеми. У проєктах створення елементів IT-архітектури Збройних Сил (3С) України, сукупність яких у перспективі має скласти Єдину автоматизовану систему управління ЗС України (САСУ ЗС України) значно підвищена складність реалізації внаслідок різноманітності організаційної архітектури, цілей i функцій окремих складових сил оборони. Відповідно в ІТ-проєктах створення елементів IT-архітектури виникають чисельні ризики, які суттєво впливають на результативність проєкту, ефективність використання бюджетів i час реалізації як окремих проєктів, так і портфеля IT-проєктів загалом. Унаслідок продовження практики “клаптикової” інформатизації з різних причин попри усі іiі вади, проєктування та розробляння елементів IT-архітектури ЗС України відрізняються за обсягом i складністю проєктних завдань, використовуваних інформаційних технологій, кваліфікаційного рівня виконавців, архітектурних рішень кожного окремого елемента IT-архітектури. Управління ризиками в IT-проєктах зі створення елементів IT-архітектури САСУ ЗС України $\epsilon$ актуальною задачею, яка передбачає науково обгрунтовану діяльність у процесі управління ризиками для кожного елемента, зокрема ідентифікацію, оцінювання, обробляння ризиків, контроль, моніторинг і безперервне коригування. Науково обгрунтоване та швидке виконання задачі оцінювання ризиків i визначення заходів 3 обробляння ризиків під час кожного етапу створення АСУ зменшує ймовірність відхилення IT-проєкту від його мети і сприяє ефективному використанню обмежених бюджетів військової організації.
Аналіз основних досліджень i публікацій. Ризики, що властиві проєктам зі створення програмних продуктів та АСУ на їх основі, описані в багатьох роботах. Наприклад, Т. Аддісон та С. Вейлабх у роботі [1] навели переліки ризиків, агреговані в таблицях і графіках за показником важливості за п'ятирівневою шкалою Лікерта. В ITпроєктах 1990 - 2000-х років після агрегації здійснене групування за трьома рівнями. До переліку увійшли такі ризики: нерозуміння обсягів, цілей і вимог проєкту; неможливість залучення користувачів (до проєкту); слабка підтримка вищим керівництвом; неправильно розроблені програмні функції; нереалістичні графіки та бюджети; постійні зміни вимог; недостатні знання/навички виконавців; відсутність ефективної методології управління проєктами; марнотратні та/або непотрібні користувачам поліпшення. 3 указаних негативних ризиків для досягнення цілей ITпроєктів чотири були визнані респондентами як найчастіші: нерозуміння обсягів і цілей проєкту; слабка підтримка вищим керівництвом; нереалістичні графіки та бюджети; постійні зміни вимог. Цінність роботи була в систематизації експериментальних даних i випробуванні підходів до вимірювання та оцінювання важливості 3 метою обгрунтування заходів 3 управління ризиками.

Дослідниця М. Самнер у роботі [2] вказала на ризики, які характерні для проєктів впровадження ERP-систем та не зустрічаються в інших проєктах:

зрілість організації (аспект 1) нездатність ефективно перепроєктувати бізнес-процеси та модель бізнесу відповідно до можливостей, які надає автоматизація звичних в минулому операцій; нездатність 
створити IT-архітектуру організації, яка підтримує інтеграцію даних; кадровий потенціал (аспект 2) недостатня внутрішня підготовка та перепідготовка у сфері інформаційних технологій; відсутність експертів, які володіють знаннями ділових процесів організації; нездатність менеджменту організації до ефективного поєднання власного досвіду та рекомендацій зовнішніх експертів; відсутність можливості найму та утримання кваліфікованих розробників ERPсистем;

розроблення програмних систем (acneкm 3) - недотримання стандартизованих специфікацій, які підтримує програмне забезпечення; відсутність інтеграції; намагання будувати “мости” до застарілих програмних систем.

За останні 20 років накопичений дослідниками досвід управління ризиками надав багато фактичного матеріалу про вплив i ймовірність виникнення типових проєктних ризиків як в індустрії програмного забезпечення, так і під час використання іiі продукції у кінцевих користувачів. Зокрема в дослідженні Абдельрафе Е. [3] було показано, що проєктні ризики значно відрізняються на кожному етапі життєвого циклу програмного продукту та автоматизованої системи. $\mathrm{Ha}$ етапі планування в трійку лідерів за частотою виникнення увійшли: слабке залучення ключових користувачів; нереалістичні графіки та бюджети; нереалістичний обсяг проєкту i цілі проєкту. На етапі аналізу $i$ концепиіï: нечіткі, неправильні або швидкі та постійні зміни вимог до програмного забезпечення; невиконання, або відсутність детального аналізу вимог; додавання розробниками функціональності, яка не входить в обсяг проєкту.

У щорічному звіті Інституту проєктного менеджменту (PMI) [4] про результати опитування учасників проєктів 3 усіх галузей економіки, зокрема в сфері IT (17\% від загального числа опитаних) за 2016 рік наведено дані про причини невдалих проєктів (респонденти вказували по три головних причини в їх організаціях). Перелік причин наведено від найчастіших до нечастих: зміна пріоритетів організації; зміна цілей проєкту; збір неточних вимог; не були визначені ризики та можливості; неадекватне розуміння мети проєкту; неточні оцінки витрат; неадекватні комунікації; недостатня підтримка вищим керівництвом; неякісне управління змінами; неточна оцінка часу на проєктні завдання; залежність від ресурсів; неадекватне прогнозування ресурсів; обмеженість ресурсів; недосвідчений керівник проєкту; прокрастинація членів проєктної команди; залежність проєктних завдань від інших проєктів.

Згідно зі звітом Standish Group [5], до переліку умов, які впливають на шість найчастіших чинників, що збільшують ризики неуспішності, входять: проєкт є великим, складним i довготривалим; особи, які зацікавлені в результатах проєкту, недостатньо кваліфіковані; проєктні процеси негнучкі; члени проєктної групи недостатньо кваліфіковані як у проєктній методології, так і в технологіях; недостатній рівень емоційної зрілості (психологічної стійкості); систематичне затягування ключових рішень проєкту (наприклад, довгий і бюрократичний процес узгодження позицій усіх зацікавлених осіб).

Науковою цінністю публікацій $\epsilon$ переліки ідентифікованих ризиків, створені шляхом обробки значної кількості емпіричних даних реальних IT-проєктів стосовно причин, що гальмували або ускладнювали досягнення мети. Переліки фокусують увагу керівників програм i проєктів на чинниках, які $\epsilon$ типовими. Проте, як правило, автори згадували методи обробки даних експертних оцінок, але не давали детального викладу опису алгоритму, яким користувались для доведення впливу та значущості, або обмежувались наданням вже готових таблиць і графіків, створених під час статистичної обробки зібраних даних. Унаслідок цього, отримання науково-прикладної цінності вже проведених досліджень потребує додаткових зусиль і розроблення зручних для практичного застосування та автоматизації методів оцінювання ризиків IT-проєктів під час планування заходів управління ризиками.

Метою статті є викладення методу числової трансформації експертних оцінок ризиків 3 використанням вербально-числової шкали Харрингтона під час типових проєктних етапів створення елементів САСУ 3 метою застосування під час обгрунтування управлінських рішень 3 планування заходів 3 управління ризиками та визначення пріоритетів, способів оброблення і обсягів інвестицій.

Виклад основного матеріалу. Більшість методологій управління ризиками частково або повністю грунтуються на використанні циклу Шухарта-Демінга для опису принципів, структури $\mathrm{i}$ процесів 
управління ризиками та мають такі складові (рис.1):

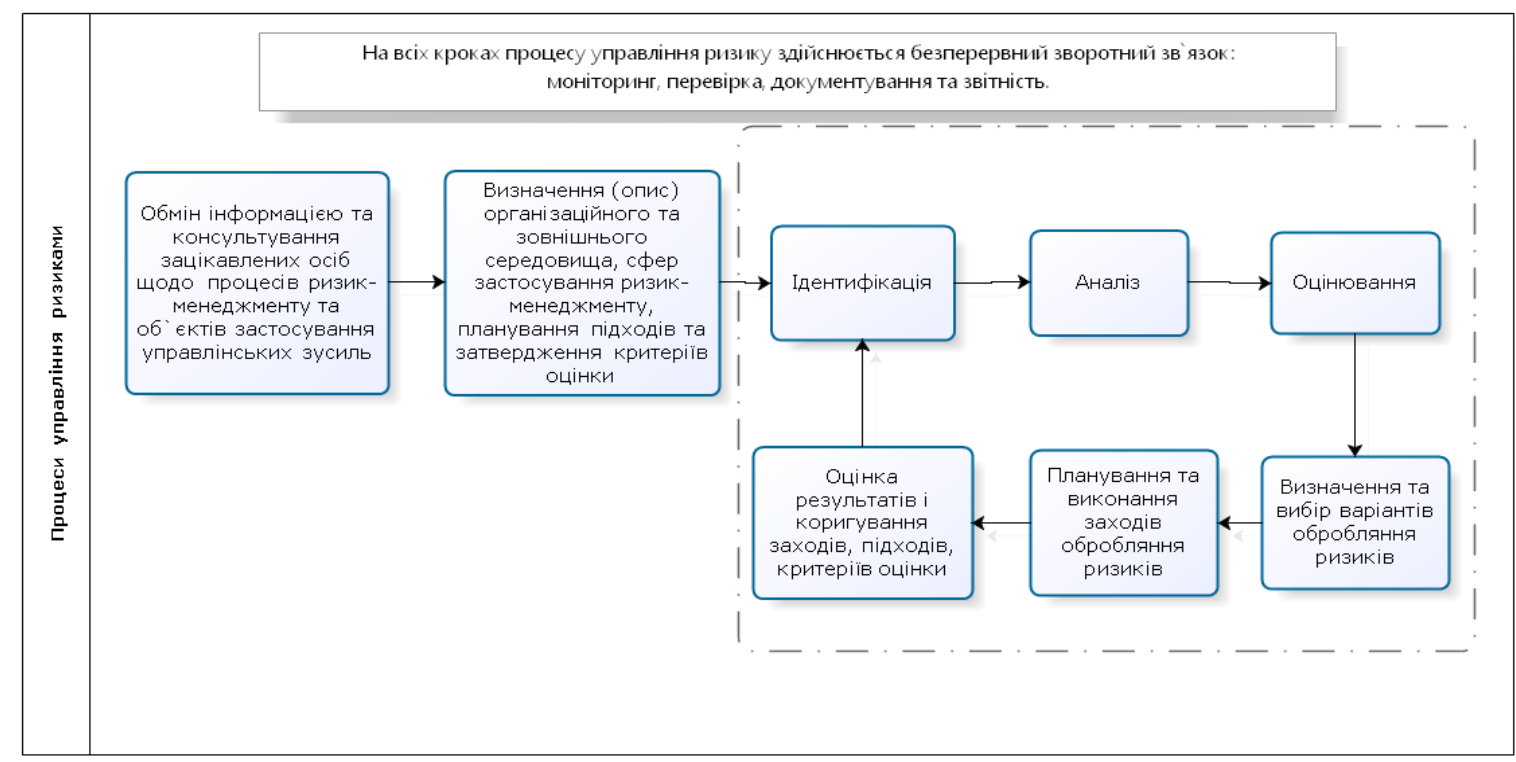

Рис. 1. Основні складові процесу управління ризиками

До процесу управління ризиками входить, як показано на рис. 1, попередня підготовча діяльність 3 підвищення зрілості організації та іiі готовності впоратись 3 проблемами, що виникають у випадку здійснення ідентифікованого ризику.

У кожному 3 переліків, наданих авторитетними експертними організаціями та наведених у наукових працях, присутні впливові та ймовірні ризики, які дещо по-різному сформульовані, але стосуються чинників властивих усім IT-проєктам. Ігнорування цих ризиків або недостатність чи хибне фокусування запобіжних заходів зумовлює високу частоту невдалих IT-проєктів. Ризики, які є типовими для проєктної діяльності в цілому впродовж життєвого циклу, наступні: нереалістичні графіки та бюджети; розбіжність між отриманим та необхідним результатом; недостатній рівень компетенції учасників проєктної команди; недостатній рівень комунікації 3 керівництвом, користувачами, підрядниками.

Проте для більш детальної ідентифікації ризиків в IT-проєктах є багато методів $[4,6]$, зокрема: анкетування або опитування учасників проєкту; аналіз проєктної документації; застосування SWOT-аналізу; застосування методу "мозкового штурму"; застосування діаграм Ішикави; побудова дерева подій; метод PDPC (діаграма процесу прийняття рішення); залучення зовнішніх експертів 3 досвідом рішення аналогічних завдань (метод Делфі) тощо. Автори статті вважають доцільним поєднання одного або декількох згаданих методів ідентифікації для попередньої кваліфікації, результатом якої $\epsilon$ множина припущень щодо ризиків. Для подальшого оцінювання ймовірності, впливу та значущості необхідно обрати методи, придатні як для трансформації в числовий формат, так і для швидкого усвідомлення управлінцями. Для переведення в числовий формат придатний i практично апробований в інших галузях і сферах діяльності метод експертної оцінки. Згладжування математичними методами та алгоритмами нечіткої логіки відхилень, викликаних суб'єктивністю експертних оцінок, дає змогу обгрунтувати варіанти обробляння ризиків i оцінити можливі обсяги профілактичних заходів. Для кожного ідентифікованого ризику експерт оцінюе ймовірність $\mathrm{i}$ вплив за вербально-числовою шкалою Харрингтона [7] (табл.1).

\section{Таблиця 1}

Вербально-числова шкала Харрингтона

для оцінювання ймовірності настання ризику та впливу на проскт

\begin{tabular}{|c|c|c|c|}
\hline Оцінка характеристики & Число & Ймовірність ризику & Вплив на проскт \\
\hline Дуже висока & 5 & $\begin{array}{l}\text { Ризик неминучий. } \\
\text { Гарантоване настання ризику }\end{array}$ & Зупинка робіт у проєкті \\
\hline Висока & 4 & Ризик ймовірний & $\begin{array}{l}\text { Виконання робіт у проєкті з великим } \\
\text { запізненням }\end{array}$ \\
\hline Середня & 3 & $\begin{array}{l}\text { Немає гарантій, що ризик настане, але } \\
\text { така можливість існує }\end{array}$ & Затримки у виконанні робіт \\
\hline Низька & 2 & Є можливість настання ризику & $\begin{array}{l}\text { Виконання робіт у проєкті з невеликим } \\
\text { запізненням }\end{array}$ \\
\hline Дуже низька & 1 & $\begin{array}{l}\text { Є потенційна можливість настання| } \\
\text { ризику }\end{array}$ & $\begin{array}{l}\text { Незначні відставання від намічених } \\
\text { планів }\end{array}$ \\
\hline
\end{tabular}


Розглянемо оцінювання ризиків на системи управління в розрізі проєктних робіт на етапі робочого проєктування.

На початковому етапі концептуального (ескізного) проєктування під час розроблення автоматизованої системи управління виконується декомпозиція системи на функціональні компоненти (елементи/модулі АCУ або програмно-технічні комплекси), прикладі створення автоматизованої

формуються черги, оцінюються часові межі виконання окремих видів проєктних робіт, ресурсне забезпечення та трудомісткість. Перелік проєктних робіт готується, як правило, у вигляді ієрархічної структури робіт (WBS). Зразок витягу з переліку та експертна оцінка значущості цих робіт (у діапазоні від 0 до 1) під час яких можуть здійснитись ідентифіковані ризики, наведено в табл. 2 .

Таблиця 2

Витяг з переліку проєктних робіт етапу робочого проєктування АСУ (витяг зі структури робіт)

\begin{tabular}{|l|c|l|l|c|}
\hline $\begin{array}{c}\text { Назви проєктних робіт етапу робочого } \\
\text { проєктування (витяг) }\end{array}$ & Днів & \multicolumn{1}{|c|}{ Початок } & \multicolumn{1}{|c|}{ Кінець } & Значущість \\
\hline Передача знань проєктній групі & 100 & Пн 28.01.2014 & Пт 14.06 .2014 & 0,3 \\
\hline Конфігурування основних даних & 50 & Пн 17.06.2014 & Пт 23.08.2014 & 0,1 \\
\hline Конфігурування процесів і документування & 50 & Пн 26.08.2014 & Пт 01.11 .2014 & 0,35 \\
\hline Розроблення додаткової функціональності & 150 & Пн 28.01.2014 & Пт 23.08.2014 & 0,10 \\
\hline Розроблення сценаріїв для тестування & 100 & Пн 28.01.2014 & Пт 14.06 .2014 & 0,15 \\
\hline $\begin{array}{l}\text { Тривалість усього періоду робочого } \\
\text { проєктування }\end{array}$ & $\mathbf{2 0 0}$ & Пн 28.01.2014 & Пт 01.11.2014 & \\
\hline
\end{tabular}

Оцінювання ризиків для окремих елементів проєкту (проєктних робіт на етапі робочого проєктування) дає змогу планувати необхідний обсяг заходів 3 управління ризиком згідно 3 обраним способом реагування. У разі незначного зростання термінів виконання одного елемента знадобиться лише пропорційне збільшення ресурсів, що не матиме вирішального впливу на хід проєкту. Проте виникнення проблем в одному значущому або в декількох взаємозалежних елементах проєкту може в сукупності вагомо вплинути на досягнення мети усього проєкту.

Пропонуємо розглянути застосування методу оцінювання експертних даних щодо ймовірності, впливу на проєкт і значущості для окремого елемента проєкту, отриманих за допомогою експертного оцінювання на прикладі ризику нереалістичних графіків та бюджетів, оскільки цей ризик є одним 3 найвпливовіших i постійних у практиці впровадження автоматизованих систем управління військового призначення в Збройних Силах України і вимагає контролю та моніторингу протягом усього проєкту за допомогою організаційних заходів i програмного забезпечення управління життєвим циклом автоматизованих систем.

Виникає питання, як підсумовувати ризики за окремими елементами і отримати загальну оцінку. Відповідь на це питання потребує побудови відповідної моделі.

На різних етапах проєкту експертні оцінки одного і того самого ризику можуть відрізнятись, а деякі ризики характерні тільки для окремих етапів проєкту і тільки для ITпроєктів $[2,3,8]$. Згідно 3 переліком робіт складається оцінка ризику для кожного елемента. Ризик "нереалістичний графік ma бюджет" властивий для всіх етапів проєкту. 3 огляду на визначення поняття “ризик”, що це деяка суб'єктивна оцінка, яка може бути виражена не в числових значеннях, а у певному діапазоні вербальних значень (наприклад, “низька”, “середня”, “висока”), тому алгоритми нечіткої логіки добре підходять для обробки таких даних, оскільки дають змогу обробляти їх через лінгвістичні змінні та функції приналежності.

Існує декілька моделей оцінювань експертних оцінок на основі нечіткої логіки під час прийняття управлінських рішень, наприклад, 3 використанням методу аналізу ієрархій Сааті [8], або шкали Лікерта [3], або оцінювання ризиків 3 використанням алгоритму Мамдані [10]. Для обчислення загальної оцінки ризику обрано як менш трудомісткий, більш наочний і придатний для швидкого практичного використання метод на основі шкали Харрингтона та алгоритму нечіткого виведення Такаги-Сугено [11].

Оскільки для оцінювання ризиків визначаються такі параметри, як вплив i ймовірність, то вони будуть використані замість перебору нечітких правил.

Додатково для кожного елемента вводиться параметр значущості, який дає змогу керувати вагою оцінки елементів відносно один до одного. Таким чином, 
оцінювання ризику за усіма елементами підсумовуватиметься за формулою 3 використанням нормалізованих числових значень впливу, ймовірності та значущості i матиме такий вигляд:

$$
y_{i}=\sum_{j=1}^{n} \bar{p}_{i j} \cdot \bar{c}_{i j} \cdot s_{j},
$$

де $\mathrm{n}$ - число компонентів;

$y_{i}$ - сумарна оцінка по $i$-у ризику;

$p_{i j}$ - нормалізована до одинці оцінка ймовірності $i$-го ризику в $j$-му елементі (межі зміни оцінки по шкалі Харрингтона коливаються від 1 до 5);

$c_{i j}$ - нормалізована до одинці оцінка впливу $i$-го ризику в $j$-му елементі (межі зміни оцінки по шкалі Харрингтона коливаються від 1 до 5);

$s_{j}-$ значущість $j$-го елемента (в діапазоні від 0 до 1).
Щоб експертна оцінка була в діапазоні від 0 до 1 , значення параметрів $p_{i j}, c_{i j}, s_{j}$ необхідно нормалізувати до одиниці:

$$
\overline{p_{i j}}=\frac{p_{i j}}{\sum_{j=1}^{n} p_{i j}} ; \overline{c_{i j}}=\frac{c_{i j}}{\sum_{j=1}^{n} c_{i j}}
$$

Для параметра значущості $S_{j}$ також має виконуватись умова: $\sum_{j=1}^{n} s_{j}=1$

Отже, ймовірність i вплив ризику оцінюються експертом за кожним елементом 3 використанням шкали Харрингтона, нормалізуються до одиниці та вносяться в таблицю числових значень ймовірності та впливу ризику для кожного елемента. Числові значення ймовірності та впливу в таблиці вказані тільки для ризику нереалістичних графіків і бюджетів $(i=1)$ за кожним 3 елементів $(j=1 \ldots 5)$, (табл. 3$)$.

Таблиця 3

\begin{tabular}{|c|c|c|c|c|c|c|c|c|c|c|c|c|}
\hline \multirow{5}{*}{ № } & \multirow{5}{*}{ Ризики } & & \multicolumn{10}{|c|}{ Елементи, що підлягають оцінці } \\
\hline & & & \multicolumn{2}{|c|}{$\begin{array}{l}\text { Передача } \\
\text { знань } \\
\text { проєктній } \\
\text { групі } \\
\end{array}$} & \multicolumn{2}{|c|}{$\begin{array}{c}\text { Конфігуру- } \\
\text { вання } \\
\text { основних } \\
\text { даних } \\
\end{array}$} & \multicolumn{2}{|c|}{$\begin{array}{c}\text { Конфігуру-вання } \\
\text { процесів та } \\
\text { документування }\end{array}$} & \multicolumn{2}{|c|}{$\begin{array}{c}\text { Розроблення } \\
\text { додаткової } \\
\text { функціо- } \\
\text { нальності } \\
\end{array}$} & \multicolumn{2}{|c|}{$\begin{array}{c}\text { Розроблення } \\
\text { сценаріїв для } \\
\text { тестування }\end{array}$} \\
\hline & & $\mathbf{j}$ & \multicolumn{2}{|c|}{$\mathbf{1}$} & \multicolumn{2}{|c|}{2} & \multicolumn{2}{|c|}{3} & \multicolumn{2}{|c|}{4} & \multicolumn{2}{|c|}{5} \\
\hline & & $\mathbf{i}$ & \multicolumn{10}{|c|}{ Ймовірність (р) Вплив (с) } \\
\hline & & & $(\mathrm{p})$ & (c) & $(\mathrm{p})$ & (c) & (p) & (c) & $(\mathrm{p})$ & (c) & (p) & (c) \\
\hline 1 & $\begin{array}{l}\text { Нереалістичні } \\
\text { графіки і бюджети }\end{array}$ & 1 & $\begin{array}{c}\mathrm{p}_{11}=0 \\
1\end{array}$ & $c_{11}=0,3$ & $\mathrm{p}_{12}=0,1$ & $\mathrm{c}_{12}=0,1$ & $\mathrm{p}_{13}=0,3$ & $\mathrm{c}_{13}=0,4$ & $\begin{array}{c}\mathrm{p}_{14}=0, \\
4\end{array}$ & $\mathrm{c}_{14}=0,6$ & $\mathrm{p}_{15}=0,2$ & $c_{15}=0,3$ \\
\hline 2 & $\begin{array}{l}\text { Розбіжність між } \\
\text { отриманим і } \\
\text { необхідним } \\
\text { результатом }\end{array}$ & 2 & $\mathrm{p}_{21}$ & $\mathrm{c}_{21}$ & $\mathrm{p}_{22}$ & $\mathrm{c}_{22}$ & $\mathrm{p}_{23}$ & $\mathrm{c}_{23}$ & $\mathrm{p}_{24}$ & $\mathrm{c}_{24}$ & $\mathrm{p}_{25}$ & $\mathrm{c}_{25}$ \\
\hline 3 & $\begin{array}{l}\text { Недостатній рівень } \\
\text { компетенції }\end{array}$ & 3 & $\mathrm{p}_{31}$ & $c_{31}$ & $\mathrm{p}_{32}$ & $c_{32}$ & $\mathrm{p}_{33}$ & $\mathrm{c}_{33}$ & $\mathrm{p}_{34}$ & $\mathrm{c}_{34}$ & $\mathrm{p}_{35}$ & $c_{35}$ \\
\hline 4 & $\begin{array}{l}\text { Недостатній рівень } \\
\text { комунікації } 3 \\
\text { керівництвом }\end{array}$ & 4 & $\mathrm{p}_{41}$ & $\mathrm{c}_{41}$ & $\mathrm{p}_{42}$ & $\mathrm{c}_{42}$ & p44 & $\mathrm{c}_{43}$ & p44 & C44 & p45 & C45 \\
\hline
\end{tabular}

Ймовірність та вплив ризиків для кожного з елементів

Наводимо приклад обчислення сумарної оцінки по $i$-му ризику на прикладі ризику "нереалістичний графік і бюджет" за цим методом 3 використанням даних 3 табл. 1, 2, 3 і отримуємо інтегрований показник ризику 3 урахуванням його ймовірності, впливу та значущості:

$$
y_{i}=\sum_{j=1}^{n} p_{i j} \cdot c_{i j} \cdot s_{i}=0,085
$$

Аналогічні розрахунки проводяться 3 рештою ідентифікованих ризиків, що дає змогу обгрунтовано підходити до визначення способів реагування. Інтегровані показники інших ризиків теж будуть у діапазоні від 0 до 1.
Переведення в числовий формат усіх ідентифікованих ризиків дає змогу відранжувати кожний ризик i визначити підходи, способи реагування та потреби в ресурсах. Метод також дає змогу оцінити в цілому рівень навантаження ризиками кожного елемента (етапу проєкту, або функціонального модуля АСУ).

Висновок. Таким чином, отримані під час розрахунків числові значення ризиків, що враховують імовірності, вплив і значущість та згладжують суб'єктивність, дають змогу керівництву організації ухвалити управлінські рішення 3 низки взаємопов'язаних питань управління ризиком. Помилки у визначенні способу реагування може завдати організації 
значних втрат, тому числові значення допомагають керівництву зорієнтуватись і сформувати для кожного ризику науково обгрунтований спосіб реагування, який дасть змогу скоротити вплив ризику на проєкт до прийнятного рівня. Сутність запропонованого підходу управління ризиками полягає у врахуванні експертних оцінок 3 урахуванням шкали Харрингтона щодо двох характеристик ризику - ймовірності, впливу та характеристики об'єкта впливу ризику - значущості етапу проєкту на основі алгоритму нечіткого виведення Такаги-Сугено та отриманні підсумкової оцінки ризику в чисельному вираженні. Результатом є можливість прийняття науково обгрунтованого управлінського рішення щодо способу обробляння усіх ідентифікованих ризиків.

За результатами дослідження запропоновано метод оцінювання ризиків як окремих елементів IT-проєкту, так i їx сукупності, як у розрізі функціональності, так і в розрізі проєктних робіт. Цей метод дає змогу підбирати спосіб реагування на кожний ідентифікований ризик.

Подальші дослідження доцільно продовжити в напрямі збирання даних та аналізу результатів практичного застосування запропонованого методу в реальних проєктах в організаціях сектору безпеки і оборони. Обробка даних може дати підстави для уточнення експертних оцінок показників ймовірності, впливу та значущості в аналогічних проєктах, відповідного рівня складності та сфери застосування.

\section{СПИСОК ВИКОРИСТАНОЇ ЛІТЕРАТУРИ}

1. Addison T., Vallabh S. Controlling Software Project Risks - An Empirical Study of Methods Used by Experienced Project Managers. Proc. SAICSIT. 2002. pp. 128-140. URL: https://people.dsv.su.se/ joco2917/ ft_gateway.cfm97.pdf.
2. Sumner M. Risk Factors in Enterprise-wide/ERP Projects. J. of Inf. Technol. 2000. № 15. P. 317-327. URL: https://www.academia.edu/1099573/Risk_factors_in_enter prise_wide_ERP_projects.

3. Abdelrafe Elzamly, Burairah Hussin, Norhaziah $\mathrm{Md}$ Salleh. Top Fifty Software Risk Factors and the Best Thirty Risk Management Techniques in Software Development Lifecycle for Successful Software Projects. International Journal of Hybrid Information Technology. Vol. 9, No 6 (2016), pp. 11-32. URL: https://gvpress.com/ journals/IJHIT/vol9_no6/2.pdf.

4. 8th Global Project Management Survey of Project Management Institute "Pulse of profession 2016". Page 23. URL: $\quad$ https://www.pmi.org/-/media/pmi/documents/ public/pdf/learning/thought-leadership/pulse/pulse-of-theprofession-2016.pdf.

5. Standish Group. CHAOS Report 2018: Decision Latency Theory: It's All About the Interval. URL: https://www.standishgroup.com/store/.

6. Николаенко В. С. Внедрение риск-менеджмента в ИТпроекты. Государственное управление. Электронный вестник. 2016. № 54. С. 63-88. URL: https://cyberleninka.ru/article/ n/vnedrenie-riskmenedzhmenta-v-it-proekty.

7. Harrington E. C., Jr. The Desirability Function. Industrial Quality Control. 1965. № 21 (10). pp. 494-498.

8. Burkovic O., Rakovic L. Risks in Information Systems Development Projects. Management. 2009. T. 4, № 1. C. 13-19. URL: http://www.ef.uns.ac.rs/mis/archivepdf/2009\%20-\%20No1/MIS2009_1_3.pdf.

9. Уткин Л. В., Симанова Н. В. Обобщение метода анализа иерархий для принятия решения при неточных сравнениях с использованием теории ДемпстераШейфера. Известия ОрелГТУ. Информачионные системы и технологии. Орел, 2007. № 4/268 (535). C. 223-227. URL: https://readera.org/obobshheniemetoda-analiza-ierarhij-dlja-prinjatija-reshenij-prinetochnyh-142144614.

10. Ехлаков Ю. П., Пермякова Н. В. Нечеткая модель оценки рисков продвижения программных продуктов. Бизнес-информатика. 2014. № 3 (29). С. 69-78. URL: https://bijournal.hse.ru/data/2014/11/25/1101705940/7.pdf

11. Титов А. И., Хомоненко А. Д. Выбор программного обеспечения с помощью алгоритма Такаги-Сугено на примере систем управления проектами. Научнотехнические ведомости СПбГПУ. Информатика. Телекоммуникации. Управление. 2016. № 1 (236). С. 41 52. URL: https://infocom.spbstu.ru/article/2016.48.5/

\section{Стаття надійшла до редакційної колегії 01.07.2020 року}

\section{Risk management of creating elements of automated control systems}

\section{Annotation}

The article provides research data on the risks of IT projects, which have been systematically observed. Among such risks are both unique, inherent, exclusively in IT projects, and typical, inherent to any other. The use of systematic risk lists facilitates the task of planning response scenarios and other measures.

However, given the fact that any risk is by definition a probabilistic event, it is necessary to solve the problem of taking into account the subjective expert assessment of probability, influence, and significance that affect management decisions regarding budgets, resources, project deadlines, and other important issues.

The method differs from the method of evaluation according to the Saati scale, the Likert scale, and the method using the Mamdani algorithm with less complexity and ease of perception. An example of estimating a typical project risk, unrealistic schedule, and budget is given. The results of risk assessment by the proposed method can be used to scientifically substantiate the directions, budgets, resources, and duration of the necessary measures to respond to the risks of creating automated control systems and other elements of the IT architecture of the UASU of the Armed Forces.

Keywords: risks of IT projects; risk assessment method, Harrington scale, the only automated control system of the Armed Forces. 